JPPUMA: Jurnal Ilmu Pemerintahan dan Sosial Politik UMA (Journal of Governance and Political Social

UMA), 8 (1) (2020): 18-27, DOI: https://doi.org/10.31289/ippuma.v8i1.2913

JPPUMA: Jurnal Ilmu Pemerintahan dan Sosial Politik UMA

(Journal of Governance and Political Social UMA)

Available online http://ojs.uma.ac.id/index.php/jppuma

\title{
The Capability of Village's Administration in the Implementation of an Effective Village Consultative Meeting Following the Indonesian Government's Regulation
}

\author{
Sofyan Effendi* \\ Department of Public Administration, Faculty of Social and Political Sciences, \\ Universitas Sriwijaya, Indonesia
}

Recieved: September 23, 2019; Accepted: February 22, 2020; Published: May 11, 2020

\begin{abstract}
One of the characteristics of Indonesian democracy is a mechanism in decision-making through a forum of discussion. The village, that stands as the lowest unit of the governance system, is also required to hold the meeting called Musyawarah Desa (village meeting). The meeting is organized following the standard and provisions in the Regulation of Minister of Village and Transmigration Affairs No. 2 of 2015 on the Procedures and Mechanism in Decision-Making in Village Meeting (Pedoman Tata Tertib dan Mekanis-me Pengambilan Keputusan Musyawarah Desa). This writing is based on the information on the capability of the village government in organizing the effective village meeting. The effectiveness of village meeting can be indicated by the elements of society that are involved in the meeting, the preparation of the meeting, procedures of organizing the village meeting and the mechanism of the meeting, which are all mentioned in the Regulation of Minister of Village and Transmigration Affairs No. 2 of 2015 on the Procedures and Mechanism in Decision-Making in Village Meeting. This research uses qualitative methods. The result shows that the village meeting has been organized effectively, in which all aspects required in the regulation has been followed. Despite being effective, six factors obstruct the process, which the village administration have to be solved to get more quality meeting.
\end{abstract}

Keywords: Village Meeting, Village Government, Effectivity

How to Cite: Effendi, S (2020). The capability of Village's Administration in the Implementation of an Effective Village Consultative Meeting Following the Indonesian Government's Regulation. JPPUMA: Jurnal Ilmu Pemerintahan dan Sosial Politik UMA (Journal of Governance and Political Social UMA), 8 (1): 19-27.

${ }^{*}$ Corresponding author:

E-mail: sofyaneffendi77@yahoo.com
ISSN 2549-1660 (Print)

ISSN 2550-1305 (Online) 


\section{INTRODUCTION}

Democracy is a system that puts public participation as the key element. According to Gatara (2008), public participation in the public domain of the democratic state is necessary as the people hold sovereignty. Indonesia as a democratic state has stipulated the principles of discussion, consensus, and representation as to the bases of the public life of the Indonesian nation. While democracy from the West is not compatible with the life of people in Indonesian. For example, the United States of America with its democracy applies a voting system in political practices in decision-making over a crucial matter that impacts people's life.

Following Risnanto (2017), 'voting' is a system in decision-making, in which the votes will determine the decision. Indonesian democracy put deliberation for consensus, which is a discussion and negotiation to seek a consensus for a solution (win-win solution). According to Pratiwi (2008), deliberation for consensus aims at strengthening brotherhood as mentioned in the fourth principle of Pancasila "Kerakyatan Yang Dipimpin Oleh Hikmat Kebijaksanaan Dalam Permusyawaratan/Perwakilan"

(democracy led by wisdom in consultation representation).

According to Hanafi (2013), democracy is practiced in everyday life to create harmony, tolerance, and brotherhood. Despite having strong autonomy, the village has to follow a good and effective democratic system with consultation for consensus in implementing its governance and program.

Law No. 32 of 2004 on Regional Governance elucidates that the village is not a subordinate unit of the regional government, but an independent community in which the community has the chance to convey aspirations based on their own interests without any intervention from the organization structure above. This makes the mechanism of village development working as 'bottom-up planning' and 'village self-planning', which certainly have to refer to the authority limits of the village administration.

Specifically, there is an institution in the village level that collects and channels the people's aspirations, the Village Consultative Body (Badan Permusyawaratan Desa/BPD), which also functions in village management. Besides, Village Administrations has to be organized strategically based on village consultation. Anything regarded to village consultation has been regulated in a regulation, which is the Regulation of Minister of Village, Development of developing area, and Transmigration No. 2 of 2015 on the Procedures and Mechanism in Decision Making in Village Meeting (Permendesa PDTTrans No. 2 Tahun 2015).

Various concepts about Village Meeting have been mentioned in the regulation, namely: (1) village meeting has been organized in the principles of participation, democracy, transparency, and accountability based on the people's right and obligation; (2) Village Meeting is organized to discuss strategic matters, namely (a) village organization; (b) village development plan; (c) village cooperation; (d) program for village investment; (e) the establishment of the village-owned company or Badan Usaha Milik Desa; (f) addition and release of village assets; and (g) extraordinary events or accident. Village Meeting is organized by Village Consultation Board (BPD) facilitated by the village administration; (3) Village Meeting is participated by the village government, the village consultation board and the civil society; (4) all elements of society that participate in the meeting can map the aspirations and necessity of the people they represent to be brought in the meeting. 
A case that becomes the locus of this study is the Village of Lorok in the Ogan Ilir Regency, South Sumatra Province. Viewed from the aspect of village development, this village is said to have executed a lot of development programs. The problem is, what becomes the basis of the development? Is the village meeting is utilized as a mechanism in decisionmaking for a solution over other problems in the village? This prompts an investigation to know further about the implementation of the village meeting in the village of Lorok. There are two main problems to be analyzed, namely (1) the effectiveness of the implementation of village meetings in Lorok Village, and (2) factors that become either obstacles or support to the implementation of village meetings by the village government.

\section{RESEARCH METHOD}

This research applies qualitative research methods. Strauss, A. \& Corbin J. (2003) defines qualitative research as a kind of research that does not generate its findings through statistics or other forms of calculations. Modes of qualitative research that are used in this research are descriptive qualitative.

According to Soehartono (1995), descriptive research aims to depict, explain, and disentangle an event with evidence from various sources displayed in scientific reasoning.

The location of this research is in the Village of Lorok, Ogan Ilir Regency, South Sumatra Province. Its unit of analysis in individuals. Arikunto (2010) defines the unit of analysis refers to the subject of the research or a unit of research subjects, which become the target of the research.

Hamidi (2005) explicates that unit of analysis is a unit of a research subject, which could be a group of individuals, social groups, objects or events in a certain context. The selection of the unit of analysis is based on the needs to answer a research question. Informants have been determined through purposive sampling, which is the selection of informants intentionally based on certain criteria. The criteria in this research are that individuals who know and understand the problems in organizing the village consultative meeting in the Lorok Village. Bungin (2007) defines informant as a person who is considered to have an understanding of data, information, and facts related to the research object.

The main source or primary source of data in this research is taken from an indepth interview with informants. Then, the secondary sources are collected from observation and study on documentation. All data that have been collected, are analyzed trough a technique borrowing from Miles and Huberman, an interactive model'. Miles dan Huberman (1992) classify the technique into three stages of activities, which in practice, appear concomitantly, namely: reducing data, displaying data, and making conclusions or verification. The verification to confirm the data in this research has been done through the technique of triangulation. Moleong (2002) explains that triangulation is a method of checking data by utilizing the other verification from outside the source, which is used as a cross-checker to the data of this research.

\section{RESULT AND DISCUSSION}

\section{Effectivity of The Village Consultative Meeting in Lorok Village, Ogan Ilir Regency}

The Indonesian Language Dictionary defines the term musyawarah as a form of the discussion held together to achieve the purpose or decision for solving a social problem. From the perspective of governance, musyawarah is a principle in the Indonesian constitution that must be necessarily followed in a democratic system to anticipate any intent of making a policy that contradicts the public interests. Simply, the manifestation of musyawarah modestly is in a meeting to seek a solution 
of the social problem, in which all stakeholders are invited to join the meeting and convey their view, from which the decision will be made collectively.

Musyawarah, or discussion, or consultative meeting, is a component that cannot be separated from the village life. According to Rozaki (2015), the village consultative meeting is a democratic instrument to institutionalize democracy in the village. The village consultative meeting is the highest forum that involves elements of society in the village. In the Minister of Village and Transmigration Affairs' regulation No. 2 of 2015, the village consultative meeting is defined as activities of discussing collectively the strategic matters about village life among Badan Permusyawaratan Desa (Village Consultative Body, Pemerintah Desa (village administration), and other social groups for a collective decision. Specifically, in the regulation, there is a mention of rights and obligations in the implementation of the village consultative meeting.

Evaluation and assessment procedures according to Minster's regulation No. 2 of 2015 can be measured by the principle of effectiveness. This principle is used as a concept that is applied to identify if the scheme of the implementation of the village consultative meeting in Lorok Village, Indrayala District, Ogan Ilir Regency has been executed effectively following the norms mentioned in the regulation.

Effectivity is related to the goals, as an activity can be said effective if it achieves well its target. Handayaningrat (1994) argues that effectivity is an assessment related to the achievement of targets as planned before. Another definition about effectivity is promoted by Tannembaum (1985), stating that effectivity can be looked or identified through the perspective of achievement of a certain target. Success in an organization is not only considering its target, but also the mechanism of persistence in pursuing its target that is already determined before. An emphasis on the relatedness between effectivity and goals is also promoted by Hidayat (1986), who explains that effectivity can be employed as a measurement in revealing the extent of success or achievement in terms of quality, quantity and time. The more percentage of targets has been achieved, the more effective an effort is.

N. Suoth, Tinangon, \& Rondonuwu (2016) state that effectivity is an interrelationship between the target and the outcome. The more massive the outputs bring to the target, the more efficient and effective the program and activities of an organization. N. Suoth et al. (2016) argues that effectivity is a state of being in which certain target is determined and is being pursued through certain instruments and their modalities, and then, can be obtained successfully with satisfaction. Effectivity in the context of the organization is also explained by Kurniawan (2005), which is the capability to execute tasks and functions (application of activities, programs, or missions) of an institution or organization in which there is no impose or tensions in their implementation. Effectivity in the context of the organization will be used in this study to assess the effectivity of the implementation of village consultative meetings according to Minister of Village and Transmigration Affairs' regulation No. 2 of 2015 on the Village Consultative Meeting.

Gibson (1996) brings forward an assessment in the context of an organization, as follows: (1) Production (2) Efficiency (3) Satisfaction (4) Excellency, and (5) Innovation. There are various approaches to measure the effectiveness of an organization. According to Campbell (1989), there are approaches to measure an effectivity in general, namely: (1) outputs of programs, (2) achievement of targets, (3) satisfaction to the programs, 
(4) comparisons of input and output, and (5) achievement of goals. Further, Robbins (2006) explains that one approach in assessing the effectiveness of an organization is the 'goal attainment approach'. In this approach, he argues that an organization is a unit formed by planning, rationale, to obtain certain goals. The approach attempts to evaluate the extent of an organization in realizing or achieving its target.

In the context of effectivity in the implementation of village consultative meeting in Lorok Village, Ogan Ilir Regency, the organization is meant as elements in the village governance, while the goals are concepts related to the meeting mentioned in the Minister of Village and Transmigration Affairs' regulation No. 2 of 2015. The goals as mentioned are as following: (1) the attainment of the public participation in the village meeting; (2) procedures in organizing the village meeting; (3) mechanism in the implementation of the village meeting; and (4) procedures in discussion and decision making for consensus.

Permendesa PDTTrans No. 2 of 2015 regulates the general procedures in the village meeting, the mechanism in discussion and, the mechanism in making decisions, and other strategic matters. Therefore, main things that assess the effectivity of the implementation of the village meeting in Lorok Village, Ogan Ilir Regency consist of following: (1) the achievement in terms of participants; (2) procedures in organizing the meeting; (3) procedures in running the meeting; and (4) mechanism in making decisions for consensus.

The first discussion here is factors that measure the effectiveness of the village meeting in Lorok Village, Ogan Ilir Regency, which is elements of society that participate in the meeting. Parameters for this achievement can be seen from the participants in the meeting, the presence of the guide of the meeting, the mechanism in inviting the participants, invitation, and guidance from the village administration to the participants.

Several interviews with informants reveal that the beholder or organizer of the meeting is Badan Permusyawaratan Desa/BPD (Village Consultative Body). Informants told also about the mechanism in inviting the participants of the meeting. It is explained that in organizing the meeting, BPD was in cooperation with the village administration in selecting and communicating those who are to be involved in the village meeting. In terms of the invitation, BPD managed through several methods, such as a letter of invitation, orally conveyed invitation, SMS, and public announcement in the praying houses. There are several elements of society and officials that were involved in the meeting, namely, the village head, the village secretary, chief of countries (Dusun), traditional figures, religious leaders, youth leaders from Karang Taruna, representative of women groups from PKK, and including the chief of sections (Kepala urusan/Kaur) in the village administration. Further about the elements of participants is the guide or tutor (pendamping) and coordinator of guide or tutors in the meeting. Informant reveals that in the meeting, a guide and tutor is someone who gives information and explains about certain matters. In the meeting, a guide or tutor who is invited were officials from the district administration.

From the above findings, it can be concluded that the achievement in public participation in the village meeting is already effective and conforms to the minister's regulation No. 2 of 2015 on the procedure and mechanism of decision making in the village meeting. Whereas, the obstacles to the achievement of public participation are the absence of participants in the meeting. This is due to the participants in the meeting have their 
own activities. Focusing on their tasks, the participants prefer not to attend the village meeting.

The following part that becomes the focus of this research is procedures in organizing the village meeting. Topics in this part are procedures of planning the activities of meeting, preparing materials, means, and equipment of the meeting, the constitution of the committee, and budget in implementing the village meeting in Lorok Village, Ogan Ilir Regency.

Interviews with informants reveal that the plan of the village meeting had been done before the meeting. In the planning stage, the organizer prepared materials to be discussed in the coming meeting. The materials, such as problem listing, have been categorized and selected, which one can be brought to the meeting and which one cannot. Another aspect that has been decided is the schedule of the meeting, place, the formation of the organizing committee, and the allocation of the budget that is possible to fund the village meeting. These things are mentioned in the Minister's regulation No. 2 of 2015 .

As informed by the informants, the preparation of the village meeting in Lorok Village, Ogan Ilir Regency, followed the technical procedures mentioned in the regulation. Besides, it has been organized by initiatives of the people who organized independently and regularly every year, in which they prepare all facilities and equipment that are needed together with the village administration and the local communities. The Schedule of the village meeting and location have been stipulated by BPD, which then announces it to the public. However, they formed the organizing committee of the village consultative meeting flexibly, which means it does not follow the regulations but has been based on their agreement.

The informants of the research also told that in the implementation of the village meeting, the administration of
Lorok Village has facilitated the activities by allocating the village budget following the regulation. However, the disbursement of the village budget from the central government often comes late, so the village administration borrowed money to finance the meeting. The money came from various sources, which were spent at the meeting. Only after the disbursement of the village budget from central government, the debt can be paid.

The last topic in the assessment of the implementation of the village meeting is looking at the mechanism in organizing the meeting program and media in discussing the problems in the meeting. As told by the informants, the program of the meeting has been arranged and the media in discussing the problems in the meeting has been prepared following the regulations.

Regarding the procedures in preparing the meeting in Lorok Village, it can be concluded that the preparation of the village meeting in the Lorok Village, Ogan Ilir Regency, has been done well enough according to the Minister of Village and Transmigration Affairs' regulation No. 2 of 2015 on the procedures and mechanism in the village meeting. Whereas, problems that often occur to be an obstacle in achieving the preparation of the village meeting is the insufficiency of the village budget to finance all activities so some of them had been suspended. This is due to many other necessities the village administration must prioritize to finance. Therefore, the preparation of the village meeting was lack of finance.

The third dimension that becomes the topic of this discussion is the mechanism of running the village meeting. In this part, topics of discussion are about the mechanism in selecting the spokesman of the meeting, secretary, guide or tutor of the meeting, procedures in explaining the programs, and mechanism in explaining the topics of the village meeting. These topics have been expanded in the 
fieldwork when the author found information that has to be investigated further.

From the information told by the informants, it can be explained that the apparatus of the village meeting is often appointed spontaneously during the meeting. Informants added that the spokesman of the meeting is the chief of BPD Lorok. The other topic about running the meeting is the procedures for explaining the meeting's program. The meeting's program is the main part or core of the village consultative meeting. In the minister's regulation, there is a mention of technical things in arranging a program at the village meeting. The principles that have been brought forward are democracy and consensus. The informants of this study explain that the meeting's program has been announced by the chief of BPD, who has been the spokesman of the meeting at the same time. The following matter is the mechanism in explaining the topics of the discussion in the meeting. The topics of the discussion have been specified to be discussed in the meeting. Following the regulation, the explanation of the topics of discussion has been regulated to be done systematically with its guidelines. According to informants, the mechanism in explaining the topics of discussion has been preceded by the person or group who brings the topics or problems. The findings of this study reveal that there is insufficient document and media used to support in conveying the topics of discussion. This is probably not an essential matter, but it plays a role in supporting the mechanism of conveying topics of discussion in the meeting.

Based on the interviews, the dimension of the mechanism of running the village consultative meeting in Lorok Village has been effective enough. It has run well in accordance with the regulation. Whereas, problems that occurred as the obstacle is a lack of supporting media to convey topics of discussion during the village consultative meeting.

The fourth dimension that will be discussed here is the mechanism in making a decision. Several matters discussed here are tasks, right, and obligations of the leaders and participants of the village meeting, procedures for guests, visitors, and journalists in the meeting. This includes also the mechanism of closing and reporting the village meeting.

Information from interviews reveals that the mechanism of decision-making for consensus in the village meeting in Lorok Village, Ogan Ilir Regency, so far has been following the regulation. This can be viewed from the conformity of the implementation of the meeting with the regulation, which is the Minister of Village and Transmigration Affairs' regulation No. 2 of 2015 on the procedures and mechanism in the decision making in the village meeting.

In the dimension of consultation and discussion in the village meeting, it can be concluded that the implementation of the above activities has been good enough according to the Permendesa No. 2 of 2015 on the procedures and mechanism in making a decision in the village meeting. Problems that often occur as the obstacle are, that, the people have not yet understood completely about the mechanism in making a decision in the meeting. So far, they assumed that their proposals have to be necessarily accepted and executed by the village administration after the meeting. However, due to many other proposals and other priorities in the village, their proposal cannot be executed in time. This misunderstanding results in the misperception of the people, assuming that their proposals have not been responded to or accepted in the village meeting. Yet the proposals could be executed in the future, in two or three years later depending on the priority of the village administration and the urgency of the problems. 
Factors that Impact the Implementation of Village Consultative Meeting in the Lorok Village, Ogan Ilir Regency

This last part of the analysis discusses the factors that impact the implementation of the village consultative meeting according to the Minister of Village and Transmigration Affairs' regulation No. 2 of 2015 in Lorok Village, Ogan Ilir Regency. Identification and the emphasis on the factors in this part will be accentuated on the obstacle factors based on the findings mentioned in the previous parts.

The first factor is ineffective communication between the village and the regency administrations, which results in less understanding of the village administration that impacts the implementation of the village meeting in the Lorok Village, Ogan Ilir Regency. The second factor is less participation from the people in the meeting, which leads to the decision-making mechanism that does not meet the regulation on the village consultative meeting. The third factor is the insufficient budget of the village to finance the village meeting, so the implementation of the meeting has been financed from the other sources. Lack of budget can fail the meeting. This can happen because many other projects funded by village administration using the same budget. The fourth factor is the difficulty in arranging the schedule of the implementation of the village meeting due to various occupations of the people, who have their own work time. The fifth factor is there are protests from the people against the result of the meeting. It is due to less participation of the people to attend the meeting. According to the Minister's regulation No. 2 of 2015, it is mentioned that every element of society that participates in the village meeting should map the people's aspirations they represent to have materials to be brought to the forum of the meeting. The sixth factor is less understanding of the people in identifying the topics in the discussion of the village meeting. People demand all of their proposals to be discussed to generate a solution in the meeting, while the village meeting has to prioritize many other problems in the village at that time. The seventh is a supporting factor, which is the independence and initiatives of the people in Lorok Village to organize all activities held in the village. As told by informants, that, despite several obstacles in the implementation of village meetings, such as lack of budget, the people can solve it collectively so that the meeting can be executed with all its achievements.

\section{CONCLUSION}

The effectiveness of the village consultative meeting in the Lorok Village, Ogan Ilir Regency is effective enough according to the Minister of Village Affairs' regulation (Permendesa) No. 2 of 2015 on the guideline, procedures, and mechanism in decision making in the village consultative meeting. Though, there are a few obstacles in its implementation. However, the conformity between the implementation of village consultative meeting and the regulations has become an indication that the meeting in the Lorok Village, Ogan Ilir Regency could be said effective enough.

Several factors are consisting of six obstacle factors and one supporting factors, which influence the implementation of the village consultative meeting in the Lorok Village, Ogan Ilir Regency according to the Minister of Village Affairs' regulation No. 2 of 2015 on the guideline, procedures, and mechanism in decision-making in the village consultative meeting. The obstacle factors are (1) ineffective communication between the Village administration and the government at the Regency level; (2) less participation from society; (3) lack of budget that can finance the village consultative meeting; (4) difficulty in making a schedule of the village meeting; 
(5) there was a dissenting opinion from the villagers on the result of the meeting; (6) the actual problems of the village are not understood properly to be discussed in the meeting. Whereas, the supporting factor that has been identified is the public initiatives to organize the village consultative meeting.

\section{BIBLIOGRAPHY}

Arikunto, S. (2010). Prosedur Penelitian Suatu Pendekatan Praktik (procedures of research a practical approach). Jakarta: PT. Rineka Cipta.

Bungin, B. (2007). Kualitatif: Komunikasi, Ekonomi, Kebijakan Publik dan Ilmu Sosial Lainnya (Qualitative: Communication, Economy, Public Policy and other Social Sciences). Jakarta: Putra Grafika.

Campbell. (1989). Riset dalam Efektivitas Organisasi (Research on the effectivity of organization) (Alih Bahasa oleh Sahat Simamora). Jakarta: Erlangga.

Creswell, J. W. (2003). Research Design Qualitative, Quantitative and Mixed Methods Approaches Second Edition. New Delhi: Sage Publications.

Departemen Pendidikan dan Kebudayaan. 1989. Kamus Besar Bahasa Indonesia. Jakarta: Balai Pustaka.

Gatara. (2008). Ilmu Politik Memahami dan Menerapkan (Political sciences, understanding and application). Bandung: Pustaka Setia.

Gibson, D. (1996). Organisasi, Prilaku, Struktur, Proses (organization, behavior, structure and process). Jakarta: Erlangga.

Hamidi. (2005). Metode Penelitian Kualitatif: Aplikasi Praktis Pembuatan Proposal Dan Laporan Penelitian (Qualitative research methods: practical application in writing proposal and research report). Malang: UMM Press.

Hanafi, M. (2013). Kedudukan Musyawarah dan Demokrasi di Indonesia (the position of consultation and democrary in indonesia). Jurnal Cita 1(2). 2 Desember. Diunduh di https://media.neliti.com/media/publication s/40848-ID-kedudukan-musyawarah-dan demokrasi-di-indonesia.pdf tanggal 9 September 2019.

Handayaningrat, S. (1994). Pengantar Studi Ilmu Administrasi dan Manajemen (introduction to the study of public administration and management). Jakarta: Penerbit Haji Masagung.

Hidayat. (1986). Teori Efektifitas Dalam Kinerja Karyawan (theory effectivity in the performance of labor). Yogyakarta: Gajah Mada University Press.

Kurniawan, A. (2005). Transformasi Pelayanan Publik (transformation of public service). Yogyakarta: Pembaharuan.

Miles, B. M. \& Huberman, M. (1992). Analisis Data Kualitatif-Buku Sumber Tentang Metodemetode Baru (Analysis of qualitative data handbook of new methods). Jakarta: UI Press.

Moleong, L. (2002). Metodologi Penelitian Kualitatif (qualitative research methods). Bandung: PT. Remaja Rosdakarya.

Peraturan Menteri Desa, Pembangunan Daerah Tertinggal dan Transmigrasi Republik Indonesia, No. 2 Tahun 2015. (2015). Pedoman Tata Tertib dan Mekanisme Pengambilan Keputusan Musyawarah Desa. Jakarta.

Pratiwi, Y. E. \& Sunarso. (2018). Peranan Musyawarah Mufakat (Bubalah) dalam Membentuk Iklim Akademik Positif Di Prodi PPKN FKIP UNILA. Jurnal Ilmu-Ilmu Sosial dan Humaniora 20(3). November. Diunduh di file://C:/Users/Asus/Downloads/1625450695-1-PB.pdf tanggal 9 September 2019.

Risnanto, S. (2017). Aplikasi Pemungutan Suara Elektronik atau E-Voting Menggunakan Teknlogi Short Message Service dan At Command. Jurnal Teknik Informatika 10(1). April. Diunduh di https://media.neliti.com/media/publication s/133605-ID-none.pdf tanggal 9 September 2019.

Robbins, S. P. (2006). Perilaku Organisasi (organizational behavior). Jakarta: PT Indeks (Gramedia).

Rozaki, A. \& Yulianto, Sg. Pelembagaan Demokrasi Melalui Musyawarah Desa (institutionalization of democracy through village consultative meeting). Yogyakarta: IRE Yogyakarta, CCES, dan HIVOS.

Soehartono, I. (1995). Metode Penelitian Sosial: Suatu Teknik Penelitian Bidang Kesejahteraan Sosial dan Ilmu Sosial Lainnya (social reseach methods: techniques of research on social prosperity and other social sciences). Bandung: PT Remaja Rosdakarya.

Suoth, N., Tinangon, J., \& Rondonuwu, S. (2016). Pengukuran Efisiensi dan Efektivitas Pengelolaan Keuangan Daerah pada Dinas Pengelola Keuangan, Pendapatan dan Aset (DPKPA) Kabupaten Minahasa Selatan. Jurnal EMBA: Jurnal Riset Ekonomi, Manajemen, Bisnis dan Akuntansi, 4(1). Diunduh di http://ejournal.unsrat.ac.id/index.php/emb 
a/article/view/11759 tanggal 9 September 2019.

Strauss, A. \& Corbin, J. (2003). Dasar-dasar Penelitian Kualitatif (basics of qualitative research). Yogyakarta: Pustaka Belajar.

Tannembaum. (1985). Efektivitas Organisasi (effectivity of orgaization). Jakarta: Erlangga. tanggal 9 September 2019.

Robbins, S. P. (2006). Perilaku Organisasi. Jakarta: PT Indeks (Gramedia).

Rozaki, A. \& Yulianto, Sg. Pelembagaan Demokrasi Melalui Musyawarah Desa. Yogyakarta: IRE Yogyakarta, CCES, dan HIVOS.

Soehartono, I. (1995). Metode Penelitian Sosial: Suatu Teknik Penelitian Bidang Kesejahteraan Sosial dan Ilmu Sosial Lainnya. Bandung: PT Remaja Rosdakarya.
Suoth, N., Tinangon, J., \& Rondonuwu, S. (2016). Pengukuran Efisiensi dan Efektivitas Pengelolaan Keuangan Daerah pada Dinas Pengelola Keuangan, Pendapatan dan Aset (DPKPA) Kabupaten Minahasa Selatan. Jurnal EMBA: Jurnal Riset Ekonomi, Manajemen, Bisnis dan Akuntansi, 4(1). Diunduh di http://ejournal.unsrat.ac.id/index.php/emb a/article/view/11759 tanggal 9 September 2019.

Strauss, A. \& Corbin, J. (2003). Dasar-dasar Penelitian Kualitatif. Yogyakarta: Pustaka Belajar.

Tannembaum. (1985). Efektivitas Organisasi. Jakarta: Erlangga. 